\title{
Liv og død i Lø Herred i 1635
}

Af SVEND JACOBSEN

Når man vil undersøge almindelige menneskers hverdag i renæssancetidens Sonderjylland, findes der næppe bedre kilder end de bevarede tingboger. De har et broget indhold af stort og småt, som menigmand ønskede en retslig afgørelse af, og som man gerne ville have et stykke papir på. Med udgangspunkt i en konkret sønderjysk tingbog fortæller forfatteren, hvordan livet blev levet - og i visse tilfælde afsluttet - i 1635.

1600-tallets tingbøger kan let give det indtryk, at datidens mennesker aldrig var alene; uanset om noget skete eller blev sagt ude på marken eller inde $\mathrm{i}$ husene, havde der tilsyneladende altid været nogen til stede. Når en sag blev rejst på tinge, kunne de tilstedeværende så indkaldes, og i tingbøgerne læser vi deres vidneudsagn. Vi får at se, hvordan en arvesag eller en ejendomsoverdragelse slutter med, at man giver hinanden hănden og takker for god afregning, og så er sagen afgjort. Vi făr at se, hvordan et ægteskab ofte er en benhård forretning mellem to familier med nøjagtige aftaler om medgift, og hvordan denne skal betales.

Tingbogen fra 1635 for Lø Herred i det vestlige Sønderjylland er ingen undtagelse, tværtimod. ${ }^{1} \mathrm{Ud}$ over et væld af eksempler på ovenstående indeholder bogen beretninger om virkelig dramatiske begivenheder. Den fortæller om eftervirkningerne af den kolossale stormflod i efteråret $1634 \mathrm{og}$ om tilfælde af manddrab, hvor straffen blev klaret ved bødebetaling ved familiens hjælp. Alene disse to forhold gør denne tingbog særlig interessant, og det må betragtes som utrolig heldigt, at den er blevet bevaret. Den nærmeste tidligere tingbog, der findes, er fra 1623, og den nærmeste senere er fra 1649.

Rent fysisk fremtræeder bogen som en lille, uanselig sag i oktavformat, som er utrolig velbevaret, dog ikke i den oprindelige indbinding. Ingen sider mangler, og kun den første og ganske enkelte af de bageste sider er en anelse beskadigede. Bogen synes at have været fugtskadet, men det har ikke haft betydning for læseligheden. 


\section{Lø Herred}

Allerede i Kong Valdemars jordebog nævnes Lø Herred (»Løghæheret«) som tilhørende Ellum Syssel. Herredets udstrækning har varieret gennem tiderne, f.eks. omfattede det oprindelig det område, der senere blev til Løgumkloster Birk. ${ }^{2}$

I 1635 omfattede herredet sognene Visby, Brede, Døstrup, Mjolden og Randerup samt de to Trøjborg'ske gårde i Kringelum i Ballum Sogn. Også den enlige, nu forsvundne gård Bysted i Ballum Enge synes ifølge tingbogen at høre til Lø Herred. ${ }^{3}$

Administrativt var forholdene mindst lige så komplicerede som i mange andre områder af hertugdømmet Slesvig. Herredet var hovedsageligt kongerigsk og skulle følge dansk lovgivning, men en del hørte til Løgumkloster Amt og skulle derfor følge slesvigsk lovgivning på visse områder (beskatning, skifte- og pantevæsen m.m.). Fire af sognene (Visby, Døstrup, Mjolden og Randerup) var blandt de såkaldte enklavesogne, som hørte under Ribe Stift, mens Brede Sogn hørte til Slesvig Stift, hvorfor slesvigsk lovgivning gjaldt i dette sogn på f.eks. fattigvæsenets område. ${ }^{4}$

Herredet sorterede i 1635 under Trøjborg Gods, som Peter Rantzau i 1579 havde overtaget med samme højhed og rettighed som kronen med »herredsting, herredstings ret, strøm, jus patronatus og $\mathrm{i}$ andre måder «. ${ }^{5}$ Ikke alle gårde $\mathrm{i}$ de ovenfor nævnte fem sogne hørte under Trøjborg, en del var som nævnt ovenfor under Løgumkloster Amt, men samtlige indbyggere i sognene var tingpligtige til Lø Herred.

\section{Herredstinget}

Det retshistoriske begreb ting kan defineres som en forsamling af befolkningen inden for et vist område til offentlig rådslagning og afgørelse af retssager. Begrebet har herhjemme eksisteret siden middelalderen og har relativt tidligt været lagt $i$ forholdsvis faste rammer, f.eks. at tinget skulle afholdes på bestemte tidspunkter og på et bestemt sted.

Almindeligvis afholdtes der ting en gang om ugen på en bestemt ugedag, som varierede efter lokale sædvaner. I Lø Herred afholdt man ting om lørdagen. Den første tingdag i et nyt år var speciel og havde ofte et specielt navn, f.eks. snapsting eller drik/druckting. Her mødte en lang række mænd op og indstævnede de, der skyldte dem 


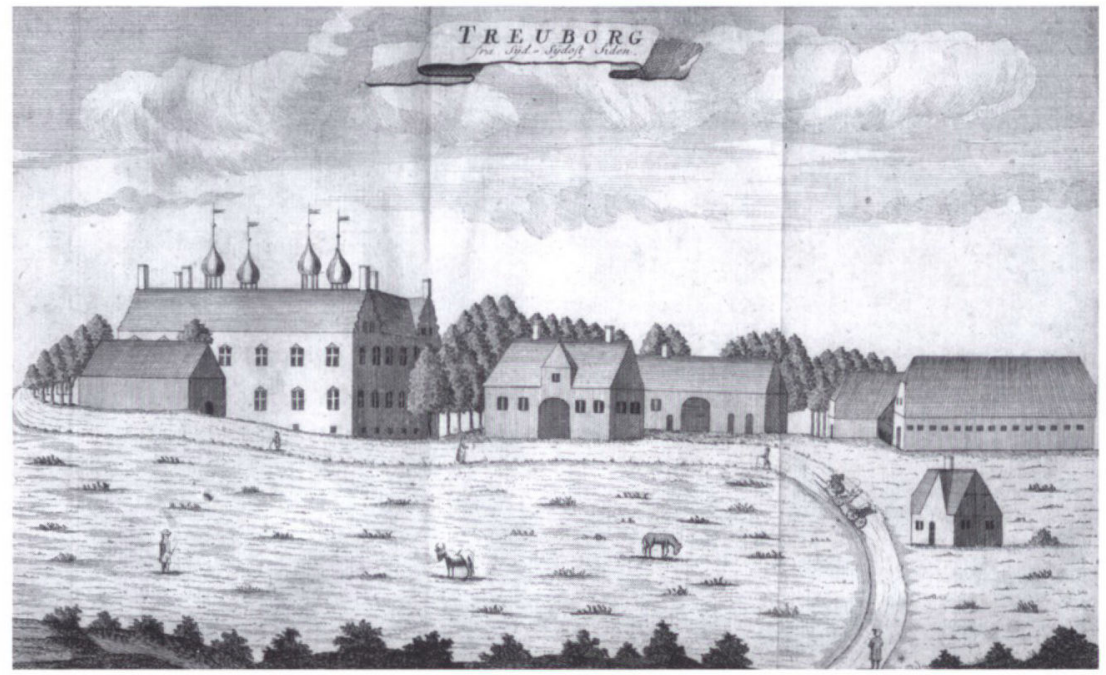

Trøjborg set fra syd-sydøst. Slottet har ikke set helt sådan ud $i$ 1635, idet Frederik von Buchwald ombyggede det $i$ barokstil $i$ 1742. J.G. Schmidts stik fra $1769 i$ Pontoppidans Danske Atlas, Tomus VII, København 1781. Foto: Museum Sonderjylland ISL-Lokalhistorie.

penge. I Lø Herred i 1635 holdtes forste ting den 10. januar og det sidste den 28 . november. På samtlige lørdage inden for denne tidsramme på nær den 28. marts foregik der et eller andet.

Oprindelig afholdtes tinget $\mathrm{i}$ fri luft inden for et område afgrænset af store sten. Oven på stenene lå nogle brædder, »tingstokkene«, og på disse sad, formentlig på bestemte fastlagte pladser, herredsfogeden, tingskriveren, tinghørerne og eventuelle øvrighedspersoner. Uden for tingstokkene kunne så alle andre af herredets beboere stå, og disse kunne så træde "inden tinge", når de skulle udtale sig eller på anden måde deltage i sagerne. I løbet af 1500- og 1600-årene flyttede man flere og flere af tingstederne indendørs, og i mange tilfælde blev der bygget specielle tinghuse. Den væsentligste grund til dette var vel, at der blev mere og mere papir involveret i forhandlingerne, dels i form af breve, der skulle fremlægges, dels i form af tingbøger, man var begyndt at føre - se nedenfor. I Lø Herred i 1635 holdt man tinget udendørs, idet der den 14. november blev skrevet i tingbogen: »Denne dag holdtes ting i Brede Kro på grund af uvejr, at man ikke kunne være ude ${ }^{6}{ }^{6}$

Det er uklart, præcis hvor tingstedet har ligget. Forskellige trykte 
kilder mener, at det har ligget i Bredebro ikke så langt fra Brede Kirke. ${ }^{7}$

I 1551 blev det påbudt alle tingskrivere i kongeriget at føre en protokol over begivenhederne på tinge og indføre domme, skøder, tingsvidner o.l. i disse, og dermed startede rækkerne af tingbøger ved landets herreds- og birketing. I byerne var påbudet kommet allerede $\mathrm{i}$ 1521..$^{8}$ De er dog ikke bevaret fra denne tid, men tidligst fra anden halvdel af 1500-tallet. ${ }^{9}$ I Lø Herred er den ældste bevarede tingbog fra 1607, derefter findes de fra 1619, 1621-23, 1635, 1649, 1682 og 16971700 .

Det var et broget persongalleri, der optrådte på herredstinget, og som vi derfor møder i tingbøgerne. Det kunne være fyrstelige embedsmænd, godsejerens repræsentanter, præster, gårdmænd og husmænd, håndværkere, købmandssvende, tjenestefolk og mange andre. Alle aldre var repræsenterede, såvel unge mænd, der havde været oppe at slås, som gamle folk, der »kunne mindes i 50 år ", at et stykke eng havde hørt til en bestemt gård.

Også kvinderne i datidens samfund optrådte, måske hyppigere end man skulle tro, men de kunne sagtens være indkrævere af gæld, og skældsordene sad lige så løst $\mathrm{i}$ munden på dem som på mændene.

Der kunne være mange grunde til, at der som regel mødte mange mennesker frem på herredstinget. En del personer var indkaldt som part i sagerne, nogle skulle vidne ("vinde" i tingbøgernes sprog), nogle havde et budskab, der skulle meddeles, og atter andre ville have et stykke papir med hjem (et »tingsvidne«), som dokumenterede et eller andet.

Derudover optrådte en række personer regelmæssigt på herredstingets scene i bestemte funktioner, som kort skal præsenteres.

Den centrale figur på tinge var herredsfogeden. Han var leder af tinget og styrede de begivenheder, der fandt sted dér. Oprindelig var det hans opgave at varetage kongens interesser, men i lobet af 1400og 1500-årene fik de udbygget deres kompetence til også at måtte dømme i nogle typer af mindre sager, og denne kompetence udvidedes efterhånden ganske betydeligt. I alvorligere sager skulle fogeden dog alliere sig med f.eks. sandemænd eller ransnævninge eller andre til lejligheden nedsatte nævn, inden han afsagde dom.

Herredsfogeden blev udnævnt af lensmanden som den nærmeste overordnede i juridisk henseende, hvilket i dette tilfælde betød herremanden på Trøjborg. Det krævede ikke nogen speciel uddannelse at 
blive udnævnt. De fleste fogeder i 1600-tallet var lokale gårdmænd, og den vigtigste kvalifikation var vel, at vedkommende havde et godt kendskab til lokalområdet og dets beboere samt en stærk social position, så han kunne udvise den rette autoritet under forhandlingerne på tinge.

Herredsfogeden i Lø Herred i 1635 hed Hans Pedersen. Han havde en helgård $\mathrm{i}$ Randerup, ${ }^{10}$ og var tredje generation af herredsfogeder fra en slægt, hvis medlemmer i øvrigt ikke altid holdt sig på den rigtige side af loven! - herom senere. Der tales i den retshistoriske litteratur jævnligt om, at der var mange uduelige fogeder, som hverken kunne læse eller skrive. ${ }^{11}$ Det har dog næppe været tilfældet med Hans Pedersen, idet det var ganske almindeligt i de sønderjyske storbondeslægter, at man kunne læse, skrive og regne. 1635-tingbogen giver ikke noget indtryk af Hans Pedersen som person, og der er $\mathbf{i}$ bogen kun indskrevet ganske få domme, som han har afsagt.

Hvis én af parterne var utilfreds med herredsfogedens afgørelse, kunne sagen ankes, og i så fald skulle det på grund af Lø Herreds status af kongerigsk enklave ske til Landstinget $i$ Viborg. Det er tilsyneladende ikke sket i $1635 .^{12}$

Hvis herredsfogeden selv var part i sagen, skulle han vige sædet, og én af sandemændene (se nedenfor) tog over som »tingholder«. Heller ikke dette indtraf i 1635.

Tingskriveren var betegnelsen for den mand, der førte tingbogen. Han var selvfølgelig også en væsentlig person, ikke mindst for os, der skal læse, hvad han skrev. Man kan overveje, hvordan han i praksis har ført tingbogen, om han har skrevet en kladde først, mens han overværede tingforhandlingerne, eller har skrevet direkte ind. For 1635-tingbogens vedkommende hælder jeg mest til det første, da bogen gennemgående er nydeligt skrevet uden ret mange rettelser, overstregninger og tilføjelser. ${ }^{13}$

Tingskriveren i Lø Herred var også skriver på Trøjborg og var som sådan ansvarlig for at føre godsets regnskab, dermed også registrene over afgifter (landgilde, fæsteafgifter) og bøder m.m. Han hed i 1635 Mathias Nielsen og boede i Bredebro. Han optræder jævnligt på tinge som herskabets repræsentant. Han fremtræeder i tingbogen med en meget personlig, markant skrift, som er nydelig og forholdsvis let læselig, når man har vænnet sig til hans specielle kruseduller på nogle af bogstaverne. Det virker, som om han er blevet mere sjusket i løbet af året, ikke skriftmæssigt, men der bliver flere delvis blanke sider, 
hvor han mangler at skrive noget ind; sager er ikke blevet afsluttet, domme ikke indskrevet o.l.

Der var forskellige andre personer, der var tilknyttet herredstingets forretninger med konkrete opgaver. Disse skal kort nævnes.

Ifølge Jyske Lov skulle der i hvert herred være otte sandemænd, som i grovere sager skulle afgive en udtalelse som grundlag for dommen, og de kunne i visse tilfælde erstatte herredsfogeden - se ovenfor. De blev udnævnt på livstid blandt de mest ansete gårdmænd, og hvervet gik ofte i arv. I 1635 nævnes de ved navn på den første tingdag, men optræder ellers slet ikke i tingbogen.

I forbindelse med røveri- og tyverisager var det ikke sandemændene, men de såkaldte ransnævninge, der var meddommere. Der var otte af dem, udvalgt blandt gårdmændene på den første tingdag, og de valgtes for et år ad gangen. I 1635-tingbogen står deres navne, men ellers optræder de slet ikke.

Tinghørerne var otte mænd, der om fornødent skulle bevidne, hvad der var foregået på tinge, og som skulle være medudstedere af tingsvidner. De udnævntes blandt gårdmændene for hver enkelt tingdag, formentlig af herredsfogeden. Kaldtes også for "stokkemænd «, da de havde deres pladser på tingstokkene.

Derudover kunne herredsfogeden udnævne en gruppe af mænd til at udføre en konkret opgave. Tingbogen giver således eksempler på, at der kunne udnævnes fire eller seks mænd til syn på jord, vurderinger af bohave eller af skader på bygninger, sædekorn o.l. Til at forlige et par stridende mænd udnævntes to eller fire mænd. Endelig er der et eksempel på, at hele 24 mænd valgtes til at give en mand et vidnesbyrd - se senere.

Endelig optræder der hver tingdag en række varselsmænd. I Lø Herred havde man åbenbart den praksis, at folk skulle indstævnes til tinge ved, at to mænd mødte op et stykke tid i forvejen på den indstævnedes bopæl og på vegne af sagsøgeren gav vedkommende varsel om at møde på tinge en bestemt dag. Det kunne være slægtninge af sagsøgeren, men man har også indtryk af, at der i landsbyerne ofte var enkelte mænd, der specielt blev foretrukket som varselsmænd.

\section{Stormfloden}

Natten mellem den 11. og 12. oktober 1634 indtraf en virkelig naturkatastrofe; en enorm flodbølge skyllede ind over hele Vadehavet og 
anrettede omfattende skader. Værst gik det ud over et område syd for den nuværende dansk-tyske grænse ved øen Nordstrand. Her lå en relativt stor $ø$, Strand, med over 8000 indbyggere i 26 sogne. Størstedelen af øen blev havets bytte ved stormfloden, godt 6000 af indbyggerne døde, og alle 26 kirker blev ødelagt. Kun tre af disse blev senere genopført på de nuværende øer Nordstrand og Pelworm. ${ }^{14}$

Men også mange andre steder forvoldte floden store ødelæggelser. Helt op til Ribe kunne den mærkes. Velkendt for besøgende $\mathrm{i}$ byen er Stormflodssøjlen på Skibbroen, hvor den øverste ring flere meter oppe markerer vandstanden i 1634, og i Domkirken angiver et mærke på væggen, hvor højt vandet stod.

I Lø Herred var det tydeligvis landsbyerne ved de store engdrag omkring Brede $\AA$, der led mest ved katastrofen, som kunne mærkes op til ti km inde i landet. Mjolden, Forballum, Randerup, Lunde, Apterp, Døstrup og Vollum blev hårdt ramt, og lige uden for herredet, i Skærbæk Sogn, blev den lille landsby Misthusum næsten helt udslettet. $^{15}$

En kolossal mængde af bygninger blev ødelagt, og tusindvis af mennesker og husdyr druknede. Tabstallene for Lø Herred er følgende: ${ }^{16}$

Mennesker: Brede Sogn: 15 druknede, alle i Apterp.

Døstrup Sogn: 19 druknede.

Mjolden Sogn: 57 druknede.

Randerup Sogn: 23 druknede.

Visby Sogn synes ikke at være blevet ramt af stormfloden.

Dyr (hele herredet): 148 heste, 614 stk. hornkvæg, 443 får, 277 svin og 108 gæs. ${ }^{17}$

Når man kender stormflodens virkninger så godt i Lø Herred, skyldes det netop, at vi har bevaret tingbogen fra 1635, hvor alle skaderne og tabene er gjort minutiøst op. Processen startede tirsdag den 3. marts, hvor en række udpegede mænd begyndte rundgangen til de forskellige landsbyer for at besigtige ødelæggelserne og vurdere tabene efter denne "Guds forfærdelige syndflod«, som den kaldes $i$ tingbogen. Alle vidneudsagnene fremlægges så på herredstinget den følgende lørdag den 7. marts. ${ }^{18}$

Man kan undre sig over, hvorfor opgørelserne over ødelæggelserne først begynder næsten fem måneder efter katastrofen. Måske har man 


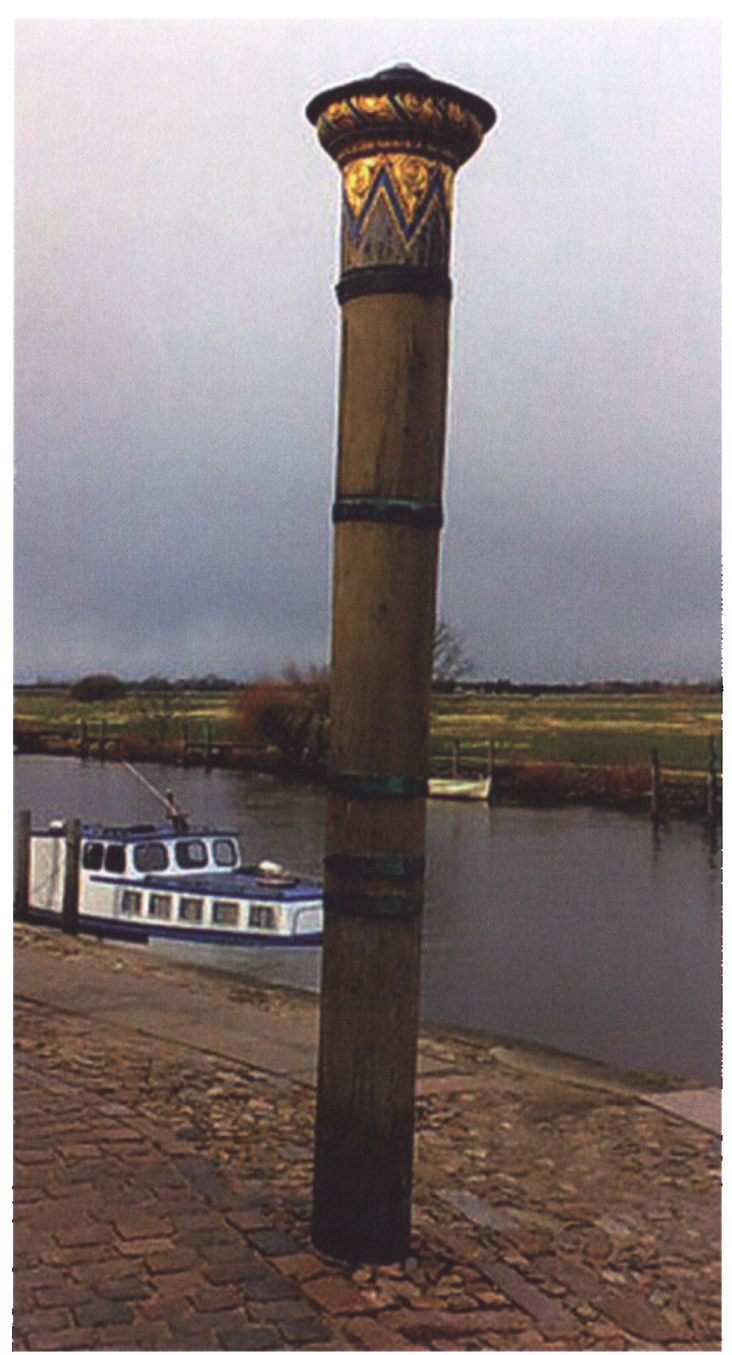

Stormflodssøjlen på Skibbroen $i$ Ribe, som vi kan se den $i$ dag. Det øoerste jernbånd pă søjlen markerer vandstandens hojde ved stormfloden $i$ oktober 1634. Privat foto.

blot ladet det hele hvile i vinterperioden. Som det fremgår nedenfor, startede man dog på visse sager affødt af stormfloden tidligere på året, og hvad man eventuelt har gjort i 1634, ved vi ikke - tingbogen er ikke bevaret. Det eneste, vi har fra dagene lige efter, er et brev dateret 16. oktober fra tingskriveren Mathias Nielsen til Fru Anne Rantzau på Trøjborg, hvori han orienterer hende om ulykken. ${ }^{19}$ Han skriver, at over 100 mennesker er druknet på de Trøjborg'ske gårde, 
og det passer jo meget godt med opgørelsen ovenfor. "Gott har gestraffet «, indleder han en af sine sætninger, og det var den almindelige opfattelse, at stormfloden var Guds straf over vadehavsegnens syndige mennesker, hvor især indbyggerne på øen Strand var berygtede for deres ukristelige liv. ${ }^{20}$

Der er skrevet om denne stormflod to gange tidligere i disse årbøger. Præsten M.H. Nielsen skrev for 110 år siden en meget stor og grundig afhandling om alt, hvad han kunne finde frem om floden med talrige tingbogscitater, ${ }^{21}$ og $\mathrm{H}$. E. Sørensen fortalte om og gengav for et par år siden en øjenvidneskildring af ulykken. ${ }^{22}$

\section{"Hvor de det finde kan«}

Ud over de meget voldsomme konsekvenser for mennesker, dyr og bygninger kan vi i tingbogen fra 1635 finde en lang række andre følgevirkninger af stormfloden, som i adskillige tilfælde også gav anledning til behandling på herredstinget, men som ikke er nævnt i litteraturen om stormfloden. Nogle eksempler på sådanne følgevirkninger skal omtales.

Vi må gå ud fra, at de efterlevende på de mange ødelagte gårde selv har bygget disse op igen, men der var selvfølgelig et problem med de gårde, hvor alle beboerne var druknet. Ikke mindst herskabet på Trøjborg, som ejede størsteparten af gårdene, var naturligvis interesserede i også at få disse ejendomme genopbygget ved hjælp af nye fæstere. Derfor møder ridefogeden Mathias Andersen op på herredstinget den 4. april og tilbyder fem gårde, om hvilke det siges, at »der er aldeles intet efterbeholden af disse ${ }^{23}{ }^{23}$ Det drejer sig om Niels Mikkelsens gård $\mathrm{i}$ Apterp, Peder Lauridsens gård $\mathrm{i}$ Lunde og tre gårde $\mathrm{i}$ Mjolden: Niels Pedersens, Hans Pedersens og Laurids Skrædders. Fælles for disse gårde er desuden, at de afdøde efterlader en del gæld, og derfor går tilbuddet også på, at en af kreditorerne frit nu og i al fremtid kan fæste en af gårdene. Det bliver dog understreget, at Fru Anne Rantzau skal have sine afgifter, »hvad de hende med ret pligtig er«; om de øvrige kreditorer så også kan få deres tilgodehavende, må den nye fæster selv klare, "eftersom de derom kan forenes «. ${ }^{24} \mathrm{Ud}$ over at blive forkyndt på tinget, blev tilbuddet også læst fra prædikestolene i egnens kirker, også i flere kirker uden for herredet: Skærbæk, Brøns, Ballum, Skast, Hjerpsted, Emmerlev, ja, selv i Tønder, alle vegne, hvor der var folk, som havde penge til gode hos de afdøde bønder. 
Det var ikke ligefrem sådan, at folk stod i kø den 4. april for at fæste og opbygge de ødelagte gårde. Det siges rent ud, at »ingen her var $\mathrm{i}$ dag, som slig gårde ville annamme $«{ }^{25}$ Det eneste positive, Fru Anne Rantzau fik ud af det, var, at en gruppe på syv mænd med sognepræsten Hr. Peder i Mjolden i spidsen næste onsdag ville mødes i Skærbæk, og dér ville de "forskaffe hende en nøjagtig mand på Niels Pedersens gård i Mjolden «. ${ }^{26}$ Dette synes også at være lykkedes, for næste tingdag, den 11. april, møder Jens Andersen i Gjesing i Skærbæk Sogn og er ikke uvillig til at ville fæste gården. Han vil dog ikke have den, »uden hvis han kunne fange med gode $«{ }^{27} \mathrm{Hvad}$ der præcis menes med det, er uklart, og tingbogen kommer ikke nærmere ind på sagen, men formentlig har han stillet nogle krav om visse fordele for at ville overtage gården.

Mere fortæller tingbogen ikke om de øde gårde, der skal bygges op. Som nævnt tidligere er der mange sager, hvis afslutning aldrig bliver nævnt. Men de bevarede fæsteregistre for Trøjborg Gods kan i dette tilfælde være et supplement, omend disse registre er noget uoverskuelige og sjusket ført. ${ }^{28}$ Det synes dog, som om tre af de ovenfor nævnte fem gårde er blevet genfæstet i 1635, og Jens Andersen er faktisk én af de nye fæstere. Han siges dog her at være fra Hjemsted, en af nabolandsbyerne til Gjesing i Skærbæk Sogn, men det skal man næppe tillægge den store betydning.

En anden gruppe af sager, der opstod i kølvandet på stormfloden, drejede sig om det vraggods af forskellig slags, der har flydt rundt $i$ vandet, og som mange har set deres snit til at tage til sig. Således havde Niels Strøms døtre, Anne og Karen, fundet to gamle trøjer og to gamle skørter. ${ }^{29}$ De bliver anklaget af Anders Knudsen i Brede, som åbenbart vidste noget om, hvem tøjet faktisk tilhørte, og han kan føre et vidne, som så, at pigerne samlede det op. Den halve side i tingbogen, hvor sagens behandling skulle være noteret, står dog tom, så vi får ikke mere at vide. ${ }^{30}$

På tilsvarende måde har en tjenestepige, Maren Jepsdatter, dagen efter uvejret fundet et skrin på Døstrup Fælled, og hun står selv på tinge den 18. juli og bekender, at hun fandt det, og at det var tomt. ${ }^{31}$ Hun forklarer så, hvordan hun sammen med sin husbonds søn, Laurids Thomsen, og Anders Christensen i Mjolden, som også var til stede, havde taget skrinet op på en vogn, som Laurids Thomsen kørte, og kommer så med en omstændelig redegørelse for, hvor det sidenhen var havnet. 
Da sagen bliver taget op igen den 8 . august, er det springende punkt, om skrinet havde været tomt eller ej. ${ }^{32}$ Anders Christensen er indkaldt som vidne, og han bekræfter forløbet og har også hørt Laurids Thomsen sige til Maren Jepsdatter, at hun måske kunne beholde skrinet, men ellers skal han ikke have noget i klemme, for han bedyrer, at han ikke har set, om skrinet var åbent eller lukket, og om der var noget i det, så han heller ikke. Det sidste kan godt undre, når han faktisk var med til at løfte det op på vognen! Også Laurids Thomsen bliver afhørt og han sværger på, at da han fik skrinet op på vognen, "da var der slet aldeles intet udi, så sandt ham Gud skal hjælpe «. ${ }^{33}$ Der bliver udstedt de sædvanlige tingsvidner på, hvem der har sagt hvad, men derefter bliver heller ikke denne sag nævnt yderligere.

Også de formentlig ret få overlevende kreaturer havnede naturligvis alle mulige steder og fristede finderne til at beholde dem. "Et brunstjernet øg med en snip på næsen og fire hvide fødder" reddede åbenbart livet i Niels Pedersens gård i Mjolden, som ellers blev totalt ødelagt, og hvor alle mennesker døde. Øget havnede hos Peder Thomsen i Mjolden, som så sidenhen solgte det til Mikkel Nielsen i Ballum-Østerende. ${ }^{34}$ Sagen rejses den 12 . september af præsten, Hr. Peder Pedersen i Mjolden, der som vidne fører Peder Hansen Rømmes i Forballum, der for fire år siden solgte den ovenfor beskrevne hest til Niels Pedersen, som "havde haft den i sin hånd og hævd og brugt det samme altid indtil den Guds forfærdelige flod kom “. ${ }^{35}$ Når det er præsten, der rejser sagen, er det, fordi han er bror til Niels Pedersen og vel derfor én af arvingerne, når nu hele dennes familie er døde; $i$ hvert fald skal han udrede en sum penge, som broderen skyldte, og da sagen tages op den 26. september, kræver han derfor et beløb hos Peder Thomsen. ${ }^{36}$ Sagen nævnes ikke yderligere, så mon ikke Peder Thomsen har betalt præsten, hvad han fik for øget.

En sag, der strakte sig gennem det meste af året, drejede sig om Jeb Frendesen og hustru Kirsten i Lunde, som begge var omkommet i stormfloden, og som åbenbart skyldte en del penge væk, da ulykken indtraf. $\mathrm{Om}$ deres gård siges det $\mathrm{i}$ tingbogen, at alt er væk undtagen et stykke lade, og alle folk er druknet. ${ }^{37}$ Sagen blev rejst $i$ januar af Jesper Andersen, som havde tjent hos Jeb Frendesen, og som havde 27 rigsdaler til gode af sin løn, og som yderligere havde lånt sin husbond 18 rigsdaler. Den 24 . januar afsiges den foreløbige («uendelige «) dom, at arvingerne skal betale ham inden 15 dage sefter kgl. Mayestæts forordning eller lyde udsætning af sit redeste gods «. ${ }^{38}$ Det sid- 
ste svarer til det, der i naboretsdistriktet Løgumkloster Birk kaldtes, at der skulle "udvurderes" noget af skyldnerens gods som betaling $\mathrm{i}$ stedet for rede penge.

Ugen efter møder Jesper Andersen selv op på tinget og sværger »ved sin sjæl og salighed «, at Jeb Frendesen skyldte ham de nævnte beløb, og han medbringer et par af de overlevende gårdmænd fra Lunde, Anders Andersen og Laurids Moritsen, som vidner. De siger bl.a., at Jesper Andersen har tjent hos Jeb Frendesen i otte år, og at denne skylder ham »en stor part af sin fortjente løn «. ${ }^{39}$

Den 14. februar møder nye personer op i sagen. Det viser sig, at Jeb Frendesen har to sønner, født uden for ægteskab, Mads Jebsen i Løgumkloster og Hans Jebsen, tjenende i Gærup, som han den 18. juni 1632 havde tinglyst $i$ den forstand, at de skulle arve 50 Mark lybsk efter hans død. De to mænd fremlægger et tingsvidne, som dokumenterer dette, og mener endvidere, at når det drejer sig om børnegods, så bør de have deres betaling af »deres salig faders restegods « forud for andre gældnere. Det giver herredsfogeden dem medhold i og dømmer, at de skal have deres part af godset, »hvor de det finde kan ${ }^{40}{ }^{40}$ og det må vel siges at være en relevant tilføjelse, når hans gods er gået helt tabt under stormfloden.

Men så nemt går det ikke. I løbet af de næste par måneder melder også kirkeværgen for Randerup Kirke, Knud Nielsen i Lunde, sig og siger, at Jeb Frendesen skyldte for 26 rigsdaler i tiendekorn, og endvidere herskabet på Trøjborg, repræsenteret ved ridefogden Mathias Andersen i Borrig, som anfører, at Jeb Frendesen skyldte landgilde. Den 4. april var alle de involverede parter mødt op på tinge og her afsiger herredsfogeden så den endelige dom: ${ }^{41}$ De tidligere uendelige domme kendes ugyldige, da der nu efter »denne skadelige syndflod befindes mere gæld end gods«, og han ved »ikke anderledes derpå at sige eller dømme" end, at først og fremmest skal kirken have sin betaling og dernæst herskabet på Trøjborg. Først derefter kommer så de to uægteskabelige sønner ind i billedet. Den stakkels Jesper Andersen, der har arbejdet i otte år uden at få ret meget af sin løn, kommer endnu længere nede $\mathrm{i}$ rækken. Herredsfogeden har sine tvivl om, hvor meget der kan realiseres, idet han slutter med at sige, at gældnerne skal have deres betaling, "så vidt som samme hans gods kan tilstrække i hvor som helst de det finde og udspørge kan må de søge deraf deres betaling « ${ }^{42}$

På en eller anden måde lykkes det alligevel at få skrabet noget 
sammen af boet til kreditorerne. Skriveren Mathias Nielsen i Bredebro førte på Trøjborgs vegne regnskab med de enkelte boopgørelser, og han kunne den 25. juli få tingsvidne på, at nu havde Knud Nielsen på Randerup Kirkes vegne samt Mads og Hans Jebsen fået deres parter af boet. ${ }^{43} \mathrm{Og}$ endelig kunne så Jesper Andersen den 24 . oktober sværge på, at han nu havde modtaget to rigsdaler af det, Jeb Frendesen skyldte ham ${ }^{44}$ - unægtelig en beskeden procentdel af den oprindelige gæld. Om han nogensinde fik resten, får vi ikke at vide.

\section{Forholdet mellem bønderne og herskabet}

I 1635 ejedes herregården Trøjborg af Anne Rantzau, "Fru Anne“, som én af bønderne kalder hende et sted. Hun var enke efter Godske Rantzau, som døde i 1616. Denne mand og hans forgænger, farbroderen Peter Rantzau, var ikke vellidte af bønderne på grund af deres krav om hoveri, og der udbrød flere gange i deres tid oprør fra bøndernes side. I 1611 blev der indgået et forlig, hvorefter det meste af hoveriet blev afløst af en pengeafgift. Dette forlig blev bekræftet af Fru Anne i 1627, så $i$ hendes tid som ejer, som varede lige til hendes død i 1650, var forholdet tilsyneladende ret fredeligt. ${ }^{45}$

Hun lader dog til ud fra det, vi kan få at vide fra tingbogen, at have været en striks dame, som ubønhørligt forlangte sine afgifter uden hensyn til undersåtternes personlige og økonomiske forhold, hvad vi allerede har set et par eksempler på ovenfor.

Den 31. januar er Anders Christensen i Randerup blevet indstævnet til tinget. Han er tiltalt af fruen for 18 rigsdaler for Hans Termansens hustrus gods (hun er vistnok hans svigermor) og for seks rigsdaler $i$ fæsteafgift. Anders Christensen træder frem og indrømmer sin gæld, men "han havde intet nu at betale med, Guds vejr og vand havde borttaget ham alt det, han havde ${ }^{46}{ }^{46}$ Herredsfogeden afsiger derefter dom med den karakteristiske indledning, som brugtes ved alle domsafsigelser: »Med flere ord og tale dem derom imellem var, da efter tiltale, gensvar og den sags lejlighed «, og fordi en udskrift af Trøjborgs register viser, at Anders Christensen i 1634 har fæstet Hans Termansens hus i Randerup for seks rigsdaler og desuden har lovet fruen 18 rigsdaler, som Hans Termansen skyldte hende, og som også skulle være betalt i 1634, og som Anders Christensen heller ikke benægter, så »efter slig forberørt lejlighed ved jeg ikke andet derpå at 
sige eller dømme" end, at Anders Christensen skal betale, hvad han skylder inden 15 dage. ${ }^{47}$

Det kunne han selvfølgelig ikke, og den 21. februar opsiger han alt, hvad han havde fæstet af hende, "det må hun selv påtage og annamme ${ }^{48},{ }^{48}$ og den 7. marts bliver han så »fordelt« af Fru Anne Rantzau, d.v.s. han bliver dømt for ikke at overholde sine forpligtelser. ${ }^{49}$ Hvad der videre sker, melder tingbogen ikke noget om.

Den 28. februar var fire mænd udnævnt af herredsfogeden til at møde i Morten Hierresens gård i Hybjerg i Mjolden Sogn. Han havde ikke kunnet betale ti rigsdaler, han skyldte fruen på Trøjborg, så derfor skal de fire mænd nu »udvurdere « noget af hans bohave, som svarer til det skyldige beløb. Mændene vælger et brunt øg, som Anne Rantzau så må beholde, medmindre han i sidste øjeblik betaler sin gæld. ${ }^{50}$

Det virker meget hårdt $\mathrm{i}$ betragtning af, at Morten Hierresen blev hårdt ramt af stormfloden; foruden adskillige køer, okser, svin og får mistede han også seks øg og heste; nu måtte han så af med endnu et $ø$ g. Megen medlidenhed med stormflodens ofre kan man ikke sige, at Fru Anne Rantzau har haft.

Personligt mødte hun ikke op på herredstinget, men lod sig repræsentere af sine embedsmænd, ridefogeden Mathias Andersen i Borrig og skriveren Mathias Nielsen i Bredebro.

\section{Mandebod}

I middelalderen var det en privatsag, hvis en mand slog en anden ihjel - det måtte drabsmanden og hans slægt selv afklare med den dræbtes slægt, og regulære slægtsfejder fandt jævnligt sted. Efterhånden blandede lovgivningen sig mere og mere i det, og på Christian IV's tid straffedes forsætligt manddrab med døden. Hvis det kunne bevises, at drabet skete ved et ulykkestilfælde eller i nødværge, slap manddræberen med at betale en bod ("mandebod «) til den dræbtes familie. Ifølge ældre dansk lovgivning var drabsmandens slægt forpligtet til at bidrage til betalingen af denne bod, men efterhånden gik man væk fra dette, og med Danske Lov i 1683 blev det fastslået, at drabsmanden alene skulle udrede boden. ${ }^{51}$ I Lø Herred i 1635 er der to eksempler på betaling af en sådan bod med bistand af slægten.

Den 13. juni møder 14 mænd op på herredstinget og bevidner og bekender, at de onsdagen før, den 10. juni, sammen med en lang række andre mænd havde været til et "frændestævne" $i$ Døstrup hos Hans 
Jensens søn, Jens Hansen. Alle de forsamlede bevilger og lover hver for sig, at de ville »bøde og godvilligen udlægge med deres frænde Jens Hansen i Døstrup hvert søskendebarn 2 rigsdaler, trediemand 1 rigsdaler og fjerdemand $1 / 2$ rigsdaler til hjælp til den ulykke og manddrab, som han desværre gjort haver «.52 I alt nævnes navnene på 66 mænd, som altså alle sammen enten selv er slægtninge af Jens Hansen eller repræsenterer en slægtning af ham. Det ses, at man gik langt ud i sidelinjerne for at indkalde frænder, en »trediemand « er en halvfætter/-kusine og en »fjerdemand « en kvartfætter/-kusine, d.v.s. en person, man har et par tipoldeforældre fælles med. ${ }^{53}$ At forsøge at finde ud af, hvordan slægt- eller svogerskabet er mellem de 66 mænd, må siges at være umuligt, idet man ville skulle tilbage til 1400-tallet for at finde en fælles stamfar. En komplikation er det også, at de 66 mænd ikke har været samtlige slægtninge, idet de 14 oprindeligt fremmødte blot siger, at der var »mange ud af vores fælles frænder « mødt op.

Det har næppe været populært hos alle at skulle bidrage til en sådan bøde, som en i mange tilfælde uhyre fjern slægtning skulle betale, og adskillige har faktisk heller ikke gjort det! Den 7. november anklager Jens Hansen på tinge 27 af sine slægtninge for ikke at have opfyldt deres forpligtelser. ${ }^{54}$ Derefter melder tingbogen ikke yderligere i sagen.

Som sagt tidligere forekommer der endnu en sag af samme slags $i$ 1635: Den 17. november var der frændestævne hos Tyge Pedersen i Randerup, som også har foretaget et »ulykkeligt manddrab«. Her var 48 frænder samlet, som vedtog, at søskendebørn skulle betale tre rigsdaler, og så tredje- og fjerdemændene gradueret derefter som før. ${ }^{55}$

De frænder, der boede uden for Lø Herred, skulle selvfølgelig også deltage $\mathrm{i}$ betalingen af boden, men kunne ikke indstævnes til Lø Herredsting i tilfælde af manglende betaling. Derfor møder Tyge Pedersen op på Løgumkloster Birketing den 7 . marts 1636 og spørger en række mænd, hvis navne han læser op, om det ikke er rigtigt, at de er befrændet med ham, ellers må de sige til. ${ }^{56}$ Når han har fået tingsvidne på det, kan han senere sagsøge dem ved birketinget for manglende betaling.

Som et appendix til den sidste sag kan man tilføje, at det ikke var første gang, Tyge Pedersen var i konflikt med loven. Ifølge bøderegistrene for Trøjborg har han i 1631 besovet Hans Nielsens steddatter i Harris, og det gør han igen i 1634! Det må siges at være noget af en overraskelse, når man nu i regnskaberne kan konstatere, at han er bror til herredsfogeden Hans Pedersen, som »aftinger « for ham. ${ }^{57} \mathrm{De}$ 


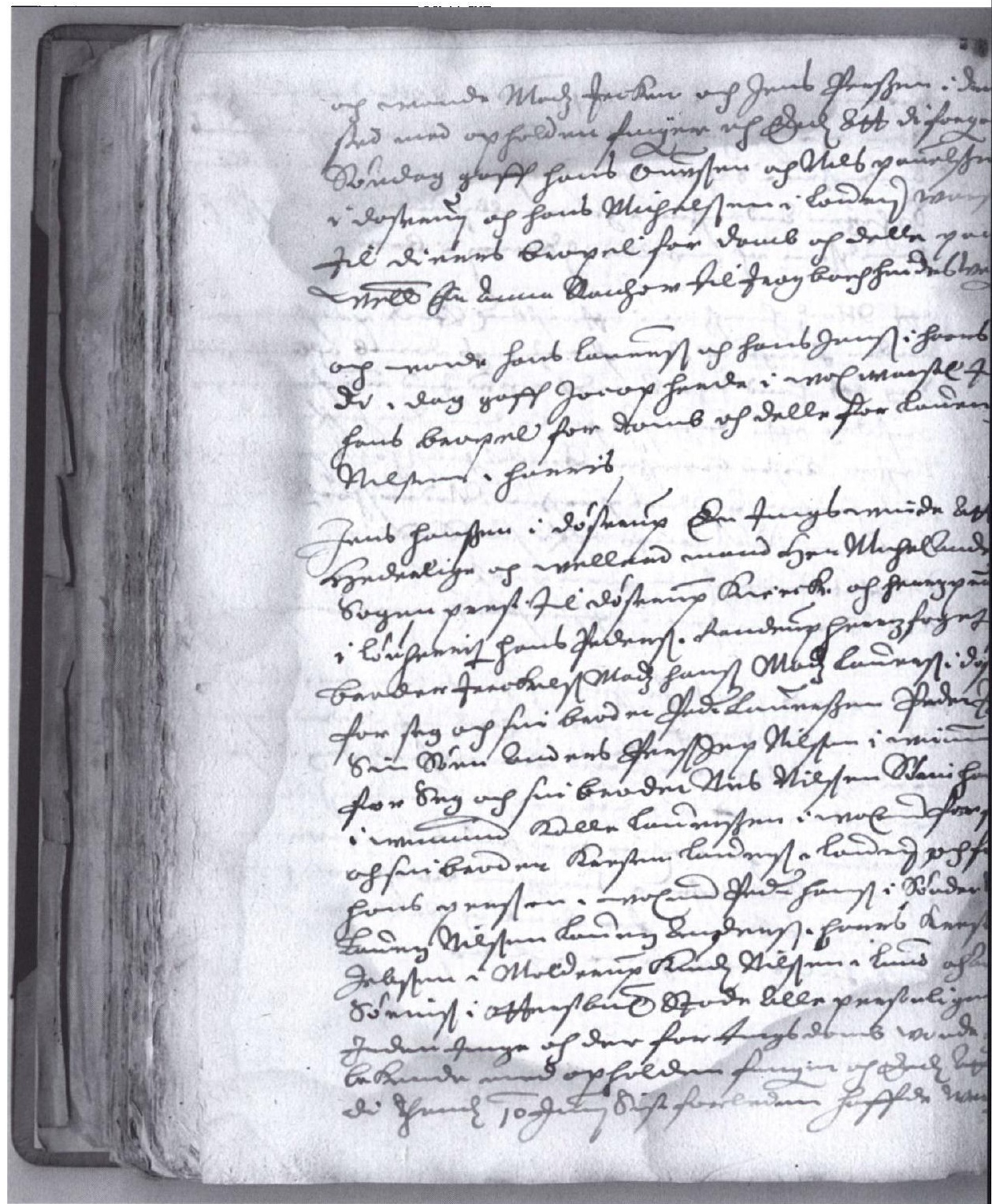

Side 171 og 172 i tingbogen, som indeholder begyndelsen af sagen om Jens Hansens begåede manddrab med beskrivelsen af frændestæonet $i$ Døstrup. Sagen starter midt på siden til venstre: "Jens Hansen $i$ Dostrup en tingsvinde att hederlig og vellærd mand Her Michel Andersen i Dostrup ...", derefter navnene på alle de af franderne, der var modt på tinge den dag. Fjerde linje fra neden: »... stode alle personlig inden 


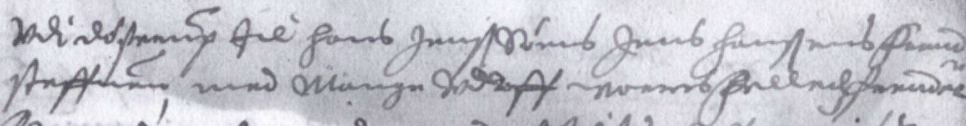

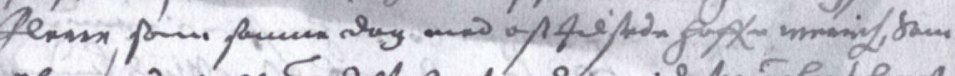

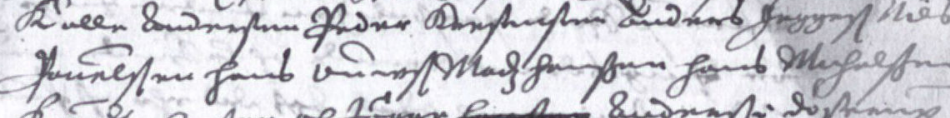
aniz far of

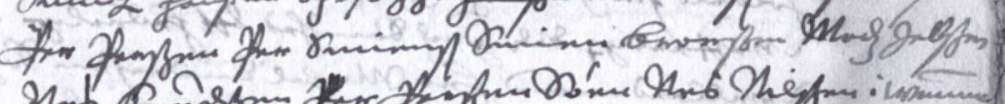

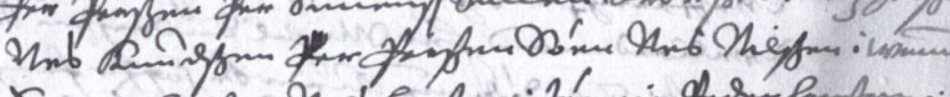

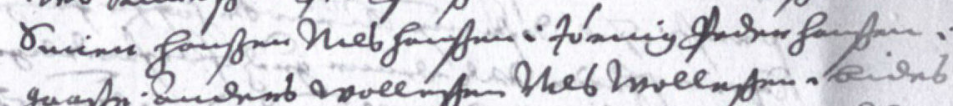
24 La

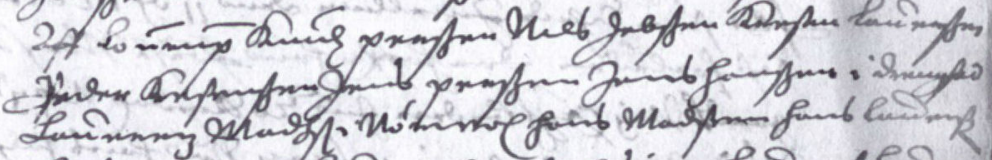

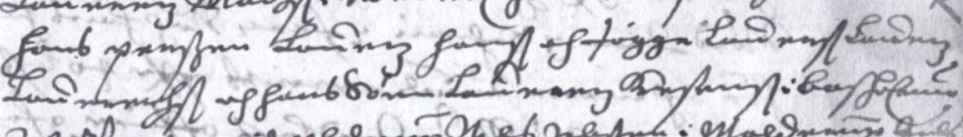

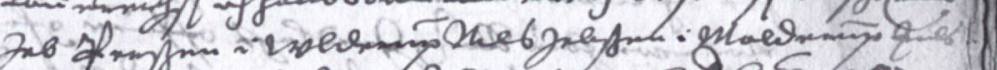

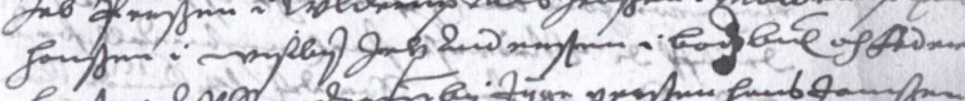

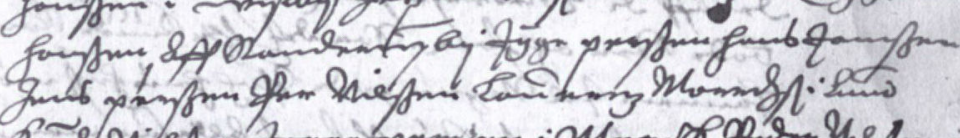

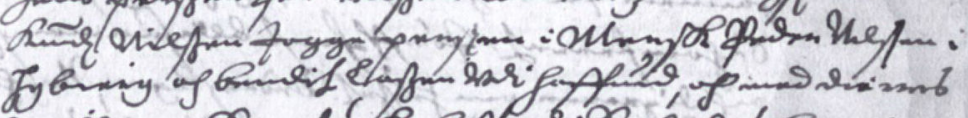

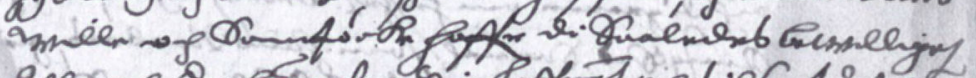

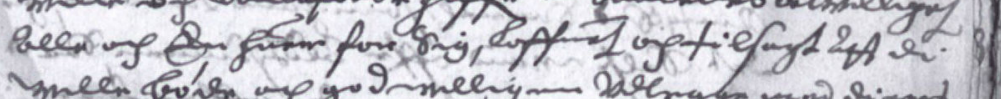

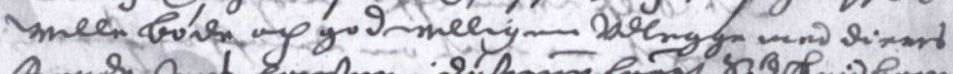

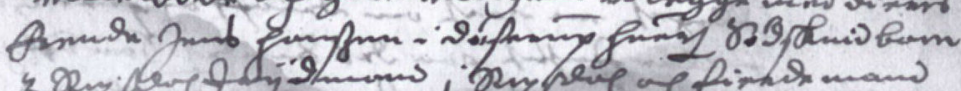

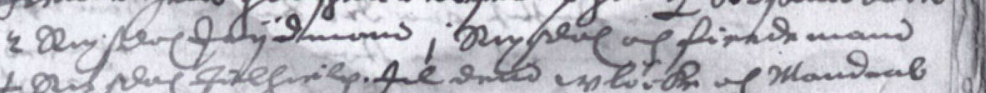

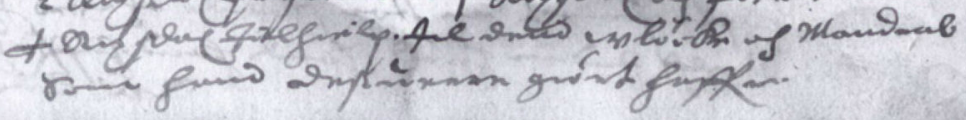

tinge og der for tingsdomb vonde och bekende med opholdne fingre och Eed, att di thend 10. Juni sist forleden ...". På side 172 folger så den lange opremsning af navne på de frander, der også skal være med til at betale mandeboden. Forst til allersidst (næstsidste linje) fär vi at vide, hoad det drejer sig om, "... uløcke och mandrab som hand desuerre giort haffuer". Foto: Museum Sonderjylland - ISL-Lokalhistorie. 
to brødres søster, Maren Pedersdatter, figurerer også i tingbogen, idet hun med broderen Tyge som lavværge den 27. juni "sigtede, sagede og beskyldte Hans Lauridsen i Randerup for hendes sandskyldige barnefar at være både for Gud og Verden $\aleph^{58}$ - ikke just nogen dydig herredsfogedslægt!

Desværre kan vi intetsteds se de nærmere omstændighederne omkring de to "ulykkelige" drab, og vi ved heller ikke, hvem der var blevet dræbt! - det melder hverken tingbøgerne eller Trøjborgs registre noget om. Men vi ved, at der skal udredes to pengebeløb: mandeboden til den dræbtes frænder og en bøde til herskabet. ${ }^{59}$

\section{En mand af ære}

Eresbegrebet var meget vigtigt i datidens samfund, og derfor blev der ved de forskellige retsinstanser ofte brugt megen tid og mange kræfter på at afklare, om en udtalelse var ærekrænkende eller ej. Omvendt var det væsentligt for en person at kunne bevise, at vedkommende var "en mand af ære ${ }^{60}$ I 1635-tingbogen findes et enkelt eksempel på en af de situationer, hvor en mand ønsker et tingsvidne på, at han er en respektabel mand, der altid har opført sig ordentligt, og vi kan konstatere, at det var en meget omstændelig og kompliceret proces.

Den 27. juni møder Niels Nielsen Skrædder, borger i Tønder, op på herredstinget og spørger »menige herredsmænd, hvad dennem i Guds sandhed var vitterligt om hans herkomst og liv og levneds forholdelse imidlertid han havde været her udi Lø Herred «. ${ }^{61}$ Det sidste handler om hans barndom og ungdom, idet han er født i Randerup. Niels Nielsen beder om, at hvis nogen vil beskylde ham eller hans forældre eller søskende for noget, så skal de stå frem og sige det.

Ingen af de »menige herredsmænd « har noget at sige, men det er ikke tilstrækkeligt. Herredsfogeden udvælger et nævn bestående af ikke mindre end 24 »lovfaste dannemænd ", og det beskrives omstændeligt, hvordan disse først går ud og forhandler og derefter kommer ind igen, d.v.s. inden for tingstokkene, og sværger på, at Niels Nielsen i sin barndom og i al den tid, han har været her i herredet, har »skikket og forholdet sig $\mathrm{i}$ al hans levned og omgængelse som en ærlig, oprigtig ungkarl «.62 De 24 mænd bevidner også, at hans forældre, som begge er født i Randerup, og hans søskende altid har opført sig "ærligt, christeligt og gudfrygtigt « $«$ ja, vi får endda at vide, at hans 
mor, inden hun blev gift, var en "ærlig, ægte og uberygtet pige«. Derefter får han så sit tingsvidne. ${ }^{63}$

Hvorfor han ville have dette tingsvidne, får vi ikke at vide. Det mest sandsynlige er, at han er kommet i vanskeligheder i Tønder, er blevet anklaget eller beskyldt for noget, så han har haft brug for at kunne bevise, at han er en ærlig mand.

\section{En skrap madamme}

Den 29. august blev en dramatisk episode, som var foregået den 20. august, rullet op på Lø Herredsting: Knud Pedersen i Forballum mødte op med to mænd, Niels Nielsen og Hans Mortensen fra samme landsby, som bevidnede, at de for ni dage siden havde været med Knud Pedersen i Kringelum for at opsøge Kirsten Hansdatter på hendes faders gård. Anledningen til besøget var lidt speciel, idet han "tilbød hende minde for den beliggelse, som han hende gjort har", og han ville efter fire uvildige dannemænds samtykke "give og betale hende «. Men Kirsten Hansdatter var ikke til sinds at tilgive ham, men svarer, at hun vil »ingen minde tage af ham, hun ville have hans liv af ham«. Derefter slår hun Knud Pedersen over armen med en tøjrekølle og smider en trefork ud ad døren efter ham. ${ }^{64}$

Dagen efter møder så Jeb Mortensen og Anders Rasmussen op på gården $\mathrm{i}$ Kringelum for at indstævne Kirsten Hansdatter og hendes værge, broderen Anders Hansen, til Lø Herredsting. Men Kirsten har igen fat i tøjrekøllen og slår Jeb Mortensen over benet med den og kaster så sten efter Anders Rasmussen. ${ }^{65}$

Det, der jo nok nu kan undre os i vore dage, er, at det faktisk er meningen, at Knud Pedersen og Kirsten Hansdatter skal giftes! - og indstævningen til tinge handler hverken om »beliggelsen« eller overfaldet med tøjrekøllen, men om den medgift, Kirsten skal have med. Den 5. september møder broderen Anders Hansen og tilbyder Knud Pedersen 400 Mark lybsk som søsterens medgift, som han lover vil blive betalt over fire terminer, desuden giver han hende kiste og sengetøj med. ${ }^{66}$ Derefter fremlægger Knud Pedersen sit skriftlige svar, gående ud på, at medgiften straks skal forelægges, og så vil han gerne gardere sig mod at få tæsk af sin kone fremover, idet han forlanger, at hendes far skal »stille mig nøjagtig visse og borgen for slag og hug i fremtiden, som hans fornævnte datter allerede begyndt har «. Hvis faderen kan garantere ham det, vil han tage tilbuddet »udi god be- 
tænkelse", men kan han ikke det, »da mener jeg, at slig tilbud ikkun at være løs snak og tale«, og at der så ikke bør udstedes tingsvidne på aftalen. ${ }^{67}$ Som så ofte før slutter sagen her, og vi får ikke at vide, om de faktisk bliver gift, eller hvad der ellers sker.

Som det også er tilfældet i andre sager, giver Trøjborgs bøde- og fæsteregistre lidt supplerende oplysninger. Det viser sig således, at "beliggelsen « allerede fandt sted i 1631, altså fire år før den refererede hændelse. ${ }^{68}$ I 1635 fæster han så en af de ødelagte gårde i Forballum efter afdøde Peder Christensen, ${ }^{69}$ og ved den lejlighed har han vel skullet finde sig en kone. Det er dog mest sandsynligt, at der allerede har foreligget en aftale mellem hans og Kirsten Hansdatters familier. ${ }^{70}$ Kirsten optræder ikke mere i kilderne, men Knud Pedersen nævnes et par gange i den følgende tingbog fra 1649 som tinghører, og videre i Trøjborgs jordebøger endnu i 1676. Gården var da en af de største i Forballum, idet han ud over den halvgård, han overtog efter Peder Christensen, i 1639 også fæstede sin fars halvgård. ${ }^{71}$

\section{Afslutning}

Ovenstående er kun et lille udpluk af de mangfoldige sager, der blev behandlet på herredstinget i året 1635. Det er med en vis fascination, man gennemlæser denne lille uanselige bog på 285 tætskrevne sider, for mange af de optrædende personer træder næsten lyslevende frem for én. Der er intet, man hellere ville, end at følge dem videre de næste år og se, hvad der sker med dem, men det kan man desværre ikke, for den næste bevarede tingbog er som tidligere nævnt først fra 1649. Nogle af personerne nævnes selvfølgelig stadigvæk, men gennemgående er det dog næste generation, der optræder. Men et utroligt tidsbillede bliver oprullet for læseren, relationerne mellem alle disse almindelige mennesker, på godt og ondt, i liv og død, for næsten 400 år siden.

\section{FORKORTELSER}

DSH: Russell, Aage (red.): Danske Slotte og Herregårde, 2. udg., Kbh. 1963-68.

SÅrb: Sønderjyske Årbøger.
Tb: Tingbogen fra 1635.

TG: Trøjborg Godsarkiv. 


\section{LITTERATUR}

Appel, Hans H.: Tinget, magten og æren, Odense 1999.

Hvidtfeldt, Johan (red.): Handbog for danske lokalhistorikere, Kbh. 1952-56.

Jacobsen, Svend: Logumkloster Birks tingbøger 1631-73, Aabenraa 2009.

Jorgensen, Poul Johs.: Dansk retshistorie, 6. opl., Kbh. 1974.

Kroman, Erik (udg.): Ribe Rådstuedombøger 1527-1576 og 1580-1599, Kbh. 1974.

\section{NOTER}

1. Tingbogen findes på Landsarkivet for Sønderjylland, retsbetjentarkiv Lø Herred m.m., nr. 2336.

2. Trap, bd. 25, s. 601.

3. Schlaber anfører, at stedet hørte til Ballum Birk, men det er næppe rigtigt. I hvert fald optræeder fæsteren Niels Simonsen i Bysted både som sagsøger, indstævnet og tinghører adskillige gange i Lo Herreds tingbøger fra $1619 \mathrm{og}$ frem.

4. Trap, bd. 25 , under de enkelte sogne.

5. DSH, bd. 16, s. 47 .

6. Tb, s. 267.

7. Trap, bd. 25, s. 602 . Schlaber, s. 350 .

8. Christian IIs landslov dette år. Hvidtfeldt, s. 485.

9. Fra Ribe købstad er der dog bevaret rådstueprotokoller fra 1527, som for de allerældstes vedkommende også fungerer som bytingbøger med referater af sagerne m.m. Kroman.

10. TG, Fæsteregister 1618: Hans Pedersen fæster sin far Peder Tygesens gård.

11. Appel, s. 550. Hvidtfeldt, s. 270.

12. Man var dog ikke altid tilfreds med Hans Pedersens afgørelser. Både i 1636 og 1637 bliver nogle af hans domme anket til Landstinget, i begge tilfælde drejer det sig om arvesager. Landsarkivet for Norrejylland, Viborg Landstings dombøger, de næunte år.

13. I tingbogen fra 1621 er en del af de bageste sider tilsyneladende brugt til at skrive kladde, idet nogle af de beskrevne sager er de samme som i den "rigtige « tekst, men skrevet meget
Russell, Aage (red.): Danske Slotte og Herregårde, 2. udg., Kbh. 1963-68.

Schlaber, Gerret L.: Administrative tilhorsforhold mellem Ejderen og Kongeảen indtil 2007 Flensborg 2007.

Sørensen, H.E.: Vadehavet - marsk og mennesker, Skærbæk 1995.

Trap, J.P.: Danmark, 5. udg., Kbh. 195872.

sjusket og streget over, formentlig når skriveren har renskrevet sagen.

14. Sørensen, s. $72 \mathrm{f}$ og $77 \mathrm{ff}$.

15. Sørensen, s. 47.

16. $S A ̊ r b .1901$, s. $76,77,85$ og 89.

17. $S A ̊ r b .1901$, s. 90.

18. $\mathrm{Tb}, \mathrm{s} .87 \mathrm{ff}$.

19. TG, pakke nr. 68: Forskelligt: Sager vedr. Stormfloder.

20. $S \AA$ rb. 1900 , s. $267 \mathrm{f}$

21. $S \AA$ rb. 1900 , s. $253-292$, og 1901, s. 57103.

22. SÅrb. 2009, s. 129-140.

23. Tb, s. 131.

24. Samme side.

25. Tb, s. 132.

26. Samme side.

27. $\mathrm{Tb}, \mathrm{s} .143$.

28. Det ser ud til, at umiddelbart efter stormfloden har man i fæsteregistret noteret alle de døde fæstere med en enslydende påtegning, f.eks. "Niels Michelsen tho Apterp ist gestorben und hefft ein halbe Gueth, schall wederumme gefestet", fulgt af en tom plads, der så i nogle tilfælde er blevet udfyldt med navne på nye fæstere og deres afgifter. Mange steder er den tomme plads ikke blevet udfyldt, men ved at folge jordebøgerne i ărene efter 1634 ser det ud til, at alle gårde og huse efterhånden fik nye fæstere. TG, fæsteregistre og jordebøger 1634ff.

29. Tb, s. 123.

30. Tb, s. 144.

31. Tb, s. 196.

32. Tb, s. 209.

33. Samme side. 
34. Tb, s. 230.

35. Tb, s. 229.

36. Tb, s. 239.

37. Tb, s. 88 .

38. $\mathrm{Tb}, \mathrm{s} .28$.

39. Tb, s. 37 .

40. Tb, s. 52.

41. Tb, s. 134.

42. Samme side.

43. Tb, s. $201 \mathrm{f}$.

44. Tb, s. 260.

45. $D S H$, bd. 16, s. 50 f.

46. Tb, s. 39.

47. Samme side.

48. $\mathrm{Tb}, \mathrm{s} .76$.

49. Tb, s. 110 .

50. Tb, s. $81 \mathrm{f}$.

51. Om mandebod og slægtens forpligtelse til at bidrage til denne, se jørgensen, s. $220 \mathrm{ff}$.

52. Tb, s. $171 \mathrm{f}$.

53. Jyske Lov satte regler for, hvilke slægtninge der skulle bidrage til mandeboden, og satte slægtskabsgrænsen ved fjerdemænd (kvartfætre eller næstnæstsøskendebørn). Jergensen, s. 221.

54. $\mathrm{Tb}, \mathrm{s} .266$.

55. Tb, s. $278 f$.

56. Jacobsen, s. 141.

57. TG, Bøderegister 1635. At Hans Pedersen aftinger for sin bror, betyder, at han forhandler med herskabet på
Trøjborg om størrelsen af den bøde, der skal betales.

58. Tb, s. 189.

59. Her slap herredsfogedens bror Tyge Pedersen med 30 rigsdaler, mens Jens Hansen skulle betale 62 rigsdaler, en umiddelbart uforståelig forskel, men måske har det været en fordel for Tyge, at han har haft herredsfogeden til at aftinge for sig. TG, Bøderegister 1635.

60. Om ærekrænkelser og eksempler på de komplicerede afgerelser af, om der forekom noget sấdant, se Appel, s. $525 \mathrm{ff}$.

61. Tb, s. 181 .

62. Tb, s. 182.

63. Tb, s. $182 \mathrm{f}$.

64. $\mathrm{Tb}, \mathrm{s} .222 \mathrm{f}$.

65. Tb, s. 223.

66. Tb, s. 226.

67. $\mathrm{Tb}, \mathrm{s} .226 \mathrm{f}$.

68. TG, Bøderegister dette år.

69. TG, Fæsteregister dette år.

70. Hans Andersen i Kringelum og sønnen Anders Hansen synes at have været ret ivrige for at få afsat datteren/søsteren, og måske kan de have brugt den gamle beliggelsessag som pression over for Knud Pedersen, som så omvendt ved sin første henvendelse på gården $\mathrm{i}$ Kringelum måske har forsøgt at købe sig fri fra et ægteskab, han ikke onskede at indgå.

71. TG, Fæsteregister dette år.

\section{Zusammenfassung}

Thingbücher aus dem 17. Jahrhundert sind eine hervorragende Quelle, wenn man sich einen Eindruck von den großen und kleinen Themen, mit denen sich das Thing beschäftigte, verschaffen will. Aus Lø Herred im westlichen Sønderjylland wurde ein Thingbuch aus dem Jahre 1635 vollständig bewahrt, eine Besonderheit, da das Buch eine detaillierte Beschreibung der Zerstörungen und Verluste nach der Sturmflut im Oktober 1634 beinhaltet. Der vorliegende Artikel berichtet von den Konsequenzen der Sturmflut, nicht ausschließlich in Bezug auf die konkreten Verluste sondern auch den generellen wirtschaftlichen Folgen. Der Artikel berichtet außerdem von einer Reihe weiterer interessanter Sachverläufe, denen sich die Rechtsinstanz in diesem Jahr widmete. So beispielsweise zwei Mordfällen sowie einigen Bespielen dafür, wie sich das Verhältnis zwischen Bauern und Obrigkeit gestaltete. 